\title{
Q. In Search of musicalia from the Baroque Library of the Augustinian Eremites in Brno
}

\author{
Hana Studeničová / H.Studenicova@seznam.cz \\ Department of Musicology, Faculty of Arts, Masaryk University, Brno, CZ
}

\begin{abstract}
In the Brno Augustinian Eremites monastery, founded in the 1450s by Margrave Jan Jindrich of Luxembourg, was around 1750 the Baroque reconstruction of the monastery completed, including a fabulous library. A collection of medieval notated manuscripts, music prints from the 16 th and 17 th centuries, treatises and several manuscript codices from the 17th century was most probably placed together in one section under the signature $\mathrm{Q}$. The volumes preserved today are easily identifiable by their uniformly arranged spines of coarse brown-black paper (in some cases, the sheets are covered with this paper) and a lighter paper label with a title written in red ink. Part of this label symbolises the collection by means of the letters Q ST, whereby $Q$ served as a sign of the shelf and ST as a sign of the convent (Sancti Thomae). They are currently stored in four institutions: the Moravian Museum, the Moravian Library, the Moravian Archives, and the Library of the Augustinian monastery at Staré Brno.
\end{abstract}

\section{Keywords}

Augustinian monastery at Staré Brno, library, church of St. Thomas, church of the Assumption of the Virgin Mary, Moravian Museum - Department of the History of Music

The article came into being as part of the project "Hudební inventáře raného novověku v českých zemích" supported by the Grantová agentura České republiky (project no. GA16-17615S). 
The Brno Augustinian Eremites monastery, founded in the 1450 s by Margrave Jan Jindřich of Luxembourg, was built due to the lack of space at the very edge of the medieval town. Its location, however, had no bearing on the importance of the monastery, which had been involved with the cultural and educational spheres of the royal city of Brno since its founding. ${ }^{1}$ For the convent of St. Thomas played a very important role in the 18th century: on the 10 May 1736, the solemn coronation of the miraculous image Virgin Mary took place; ${ }^{2}$ around 1750 the Baroque reconstruction of the monastery was completed, including a fabulous library; and in 1752 the monastery was promoted to an abbey. But just after some thirty years came a fatal blow, when in 1783 the monks were forced to leave their newly rebuilt monastery at St. Thomas (as the result of a decree by Emperor Joseph II) and move to the abandoned area of the former monastery of Cistercian nuns at Staré Brno.

From a musicological point of view, the convent is named in pious foundations (piae fundationes), which were often directly connected with musical performance in the Church of St. Thomas (the donors, for example, determined in their last wills how many masses were to be read or sung after their deaths). The most important of these is the musical foundation from the second half of the 17th century established by Sibylla Polixena Františka of Montani, née Countess of Thurn and Wallsassin. This foundation was somewhat different in nature, since it served primarily for educating youth in music or singing. ${ }^{3}$ It was thanks to this music seminary that the Augustinian monastery acquired its greatest fame, especially in the 18th and 19th centuries. The school had a director, teacher, prefect and chaplain, through which it trained excellent musicians and singers. The abbot Cyrill František Napp is considered to be the first prominent personality of this seminary, but its greatest renown came especially in the second half of the 19th century through Pavel Křížkovský and, among the students, Leoš Janáček. ${ }^{4}$ Also significant is the large collection of music (mostly from the $18^{\text {th }}$ and $19^{\text {th }}$ centuries), of which the largest part has been deposited in Department of Music History of the Moravian Museum.

A collection of medieval notated manuscripts, music prints from the 16th and 17th centuries, treatises and several manuscript codices from the 17 th century, little known

1 For the history of the Augustinian monastery, see in particular JANETSCHEK, Clemens d'Elpidio. Necrologia Patrum et Fratrum Ord. Erem. calceat. S. Aug. in vicariatu Moraviae ab anno 1363-1888 defunctorum. Brunae 1894; JANETSCHEK, Clemens d'Elpidio. Das Augustiner-Eremitenstift S. Thomas in Brünn. Bd. 1, Brünn 1898. A major cultural and historical contribution is the article by Vladislav Dokoupil, see DOKOUPIL, Vladislav. Dějiny morauských kläšterních knihoven ve správě Universitni knihovny v Brně. Brno, 1972. For general information about the Augustinians and music, see TROLDA, Emil. Augustiniáni a hudba. Cyril, 1936, Nr. 1-2, p. 7-10; 1936, Nr. 3-4, p. 29-35.

2 MALÝ, Tomáš. Civic Ritual, Space and Imagination: Coronation of the Icon from Brno (1736). In Foletti, Ivan; Palladino, Adrien. Ritualizing the City. Collective Performances as Aspects of Urban Construction from Constantine to Mao. Roma: Viella, 2017, p. 157-180.

3 For more information about the foundation and the beginnings of the music school, see ŠTĚDROŇ, Bohumír. Základy fundační kapely v Brně před Kř́̌žkovským. Slezský sbornik, 1951, Nr. 49, p. 155-183.

4 About the music school see SEHNAL, Jiř́i. Hudba u brněnských augustiniánů v 18. století. Hudebni věda, 1983, 20, Nr. 3, p. 231-241; ZLÁMAL, Bohumil. Komu také děkovati za P. Křřžkovského. (Starobrněnský opat Cyril Fr. Napp.) Cyril, 1936, Nr. 3-4, p. 36-38; 1936, Nr. 5-6, p. 60-64, 1936, Nr. 7-8, p. 81-84. 
today, are especially worthy of attention. They are currently stored in four institutions: the Moravian Museum, the Moravian Library, the Moravian Archives, and the Library of the Augustinian monastery at Staré Brno. These volumes were probably placed together in one section under the signature $Q$, when the whole library was reorganized around the middle of the 18th century. The volumes preserved today are easily identifiable by their uniformly arranged spines of coarse brown-black paper (in some cases, the sheets are covered with this paper) and a lighter paper label with a title written in red ink. Part of this label symbolises the collection by means of the letters $Q$ ST, whereby $Q$ served as a sign of the shelf and ST as a sign of the convent (Sancti Thomae).

The main objective of this study is to attempt a reconstruction of the structure of the music collection from the Augustinian monastery library based on these volumes marked $Q$ and to follow traces of preserved musicalia through to the present. It is already obvious that this is not just a case study mapping the musical history of one ecclesiastical institution, but the results contribute, among other things, to an understanding of the earliest phase of the music history of Brno, where lots of questions still remain. ${ }^{5}$

The Brno Augustinian monastery must have been musically active as a church organization from the start of its foundation. Besides liturgical sources, other valuable materials concerning musical life in the monastery have been preserved from the end of the $14^{\text {th }}$ century. For example, the prior of the Augustinian monastery, Phillipus de Brunna, is named "peritissimus organa construendi artifex" ${ }^{6}$ This proof of musical activity is, however, only indirect. From the fifteenth century, only minimal information is presently known. In 1501, an obituary mentions the organist Joannes Sinzendorfer, and in 1512 the cantor and regenschori Ambrosius Haering passed away. ${ }^{7}$ An organist with four choralists is documented in the monastery in $1571 .{ }^{8}$ Preserved Renaissance prints also prove that at the end of the 16th century polyphonic music was being cultivated by the Augustinians in Brno, as was the case at the parish church of St. James in Brno ${ }^{9}$ or in in the Premonstratensian monastery in Zábrdovice, close to the city. ${ }^{10}$

5 MAŇAS, Vladimír. Toulky po začátcích hudby v Brně. Brněnská hudebni historie [online] 2013, [cit. 201805-28]. Available from 〈http://www.mestohudby.cz/publicistika/clanky/toulka-po-zacatcich-hudby-v-brne〉.

6 JANETSCHEK, Clemens d'Elpidio. Necrologia Patrum et Fratrum Ord. Erem. calceat. S. Aug. in vicariatu Moraviae ab anno 1363-1888 defunctorum, op. cit., p. 6; JANETSCHEK, Clemens d'Elpidio. Das Augustiner-Eremitenstift S. Thomas in Brünn, op. cit., p. 39.

7 JANETSCHEK, Clemens d'Elpidio. Necrologia Patrum et Fratrum Ord. Erem. calceat. S. Aug. in vicariatu Moraviae ab anno 1363-1888 defunctorum, op. cit., p. 11-12.

8 JANETSCHEK, Clemens d'Elpidio. Das Augustiner-Eremitenstift S. Thomas in Brünn, op. cit., p. 160.

9 On the musical history of the parish church of St. James in the 16th century, see most recently STUDENIČOVÁ, Hana. Kantoři, varhaníci a věžní u sv. Jakuba v Brně v 16. století. In Brno v minulosti a dnes. Archiv města Brna, 2017, Nr. 30, p. 127-145. For preserved manuscripts of polyphonic music, see HORYNA, Martin - MAŇAS, Vladimír. Two Manuscripts of Polyphonic Music in Brno from the Mid-Sixteenth Century. Early Music, 2012, 40, N. 4, p. 553-575; MAŇAS, Vladimír. Rukopisy renesanční polyfonie - zapomenutá a přitom cenná součást svatojakubské farní knihovny. In Brno v minulosti a dnes, Archiv města Brna, 2013, Nr. 26, p. 39-49.

10 For more information on musical activities in Zábrdovice monastery, see STRAKOVÁ, Theodora. Vokálně polyfonní skladby na Moravě v 16. a na počátku 17. století. III. Hudební instituce na Moravě a jejich repertoár. 
Most information about the library of the Augustinian monastery is known thanks to the research of Vladislav Dokoupil. His main work, dedicated to the history of monastic libraries in southern Moravia (Dějiny moravských klášterních knihoven), ${ }^{11}$ describes the fate of the Augustinian library from its beginning until the year 1950, when monastic life in Czechoslovakia was violently interrupted by the regime. As Dokoupil states, the first report of the library's existence comes from the year 1571, when a visitation took place in the convent. At that time, the library contained only 238 volumes (probably just the sum of books in the main hall, not in the whole convent). Nevertheless, the library had been built systematically since the convent was established. The oldest items were typically liturgical books for daily use: graduals, antiphonaries, missals and other manuscripts. Beginning in the second half of the 15th century, there was an intensive expansion of the library, and the number of books and manuscripts would grow to substantial proportions over the centuries. Today, the library has nearly 27.000 items and belongs among the largest historical collections in Brno.

The first attempt to create a catalogue of the library took place in 1668, but today no such catalogue from that period has been preserved. Around 1748 the prior Matthaeus Pertscher made a remarkable accomplishment in completing the reconstruction of the convent, including the magnificent new library hall. ${ }^{12}$ At that time, the post of librarian was held by Adeodatus Hanzeli, who was at the same time prior of the monastery in Jevíčko, the Brno subprior, magister novitiorum, as well as the long-time secretary and the praeses of the Marian confraternity in Brno. ${ }^{13}$ For the purpose of cataloguing all the books and arranging them in the new library, Hanzeli compiled in 1748 the first library catalogue: L. I. C. Catalogus universalis instructae novae bibliothecae conventus brunensis sancti thomae Apostoli. Matthael Pertscher Infulati perpetui praelati expensis industrius exornatae. Direxit, et Instruxit P. Adeodatus Hanzelius p. $t$. Bibliothecarius $m$. $p$. According to Dokoupil, the catalog was rather vague and did not even provide signatures. ${ }^{14}$ Unfortunately this catalog has not yet been located (given his detailed description, Vladislav Dokoupil must have seen it in 1950). The first preserved catalogue of the Augustinian library from the time before the convent moved to Staré Brno is Catalogus classicus omnium librorum in majori Brunaeo-Thomensi Ord. Fr. Erem. S. P. Augustini Bibliotheca reperibilium concinnatus A. 1753, which is deposited in the Moravian Library in the Department of Old Manuscripts and Prints under the shelfmark A $3 .{ }^{15}$ The author of the catalogue is

Časopis Moravského muzea, 1983, Nr. 68, p. 151-152; MAŇAS, Vladimír. Hudebni kultura rudolfínské Moravy. In print.

11 DOKOUPIL, Vladislav. Dějiny moravských kläšternich knihoven ve správě Universitni knihovny v Brně. Brno, 1972.

12 A detailed description of the work at the library, including the final description of the hall, is available in DOKOUPIL, Vladislav. Dějiny morauských klästernich knihoven, op. cit., p. 99.

13 About Brno Baroque religious fraternities, see MALÝ, Tomáš - MAŇAS, Vladimír - ORLITA, Zdeněk. Vnitřní krajina zmizelého města. Náboženská bratrstva barokního Brna. Brno, 2010. Specifically, about Hanzeli see DOKOUPIL, Vladislav. Dějiny moravských klästernich knihoven, op. cit., p. 100-103.

14 DOKOUPIL, Vladislav. Dějiny moravských kläšternich knihoven, op. cit., p. 101.

15 Moravian Library, Brno, Department of Old Manuscripts and Prints; Ms. A 3. 
unknown, but it is likely that it was written by someone other than Hanzeli. ${ }^{16}$ Thanks to this catalogue, it is possible to determine that the library was at that time organized according to fields marked with the letters A-Z. Therefore, it is to be expected that under the letter $Q$ in this catalogue, a list of the music collection should be found. However, an initial study of this catalogue indicates that the letter $\mathrm{Q}$ includes only "Libri historiae profanae". Another smaller, alphabetically ordered catalogue dates back to 1755, Catalogus Alphabeticus Omnium Authorum Quorum Opera in Majori Brunaeo-Thomensi Ordinis Fratrum Eremitarum Magni S. P. Augustini Bibliotheca Reperiuntur. Consinnatus M. D. CC. $L$. $V$., which is today kept in the monastery library at Staré Brno. ${ }^{17}$

Why the preserved catalogue A 3 of 1753 does not contain any prints or manuscripts concerning music can be easily explained. The division of the library into the letters A-Z, that is, a total of twenty-four branches, was not applied to the entire library, but only to those books housed its main, representative hall. Already at the time of the Baroque reconstruction in the middle of the $18^{\text {th }}$ century, there were several other smaller rooms in which the remaining books were stored. Even these adjoining halls were divided according to certain categories and marked with alphabetic letters. The same is true today in the library of the monastery in Staré Brno, where, in addition to the main hall, there are also four other side rooms used to store books. The main hall bore primarily a representative function; prior Pertscher and librarian Hanzeli had made sure that the books would have a dignified but, above all, uniform appearance thanks to new bindings. Most of these books were codices in folio format, which are now easily recognizable due to the white parchment, red labels and golden letters on the front plates and spines, which originated sometime in the late 1740s. Labels with signatures and the monogram of the convent were placed at the bottom of the spines. ${ }^{18}$ At the same time, other books from the adjoining halls were joined by means of the brown-black paper mentioned above.

Alois Filip Pazderka, who served as a librarian in the monastery beginning in 1915, reorganized the library completely. This has proven consequential for understanding the form of its previous structure and books catalogued under $Q$ as well. Within several years Pazderka succeeded in cataloguing the entire library and created a leaflet catalogue and local checklist for revision purposes..$^{19}$ Concerning the present structure of the library hall and its adjacent rooms, the shelves with individual letters are still found, but without the original thematic organization from the mid-18th century created by the librarian Adeodatus Hanzeli. Even if revision lists were discovered today, it would be very difficult to find all the original musical sources belonging in the second half of the $18^{\text {th }}$ century to the department labeled $Q$, due to these lists' character as positional catalogues.

16 According to Dokoupil, Hanzeli was certainly a librarian in 1744-1750. See DOKOUPIL, Vladislav. Dějiny moravských klästerních knihoven, op. cit., p. 102. In addition, it seems unlikely that the same person would have created three catalogues in such a short period of time.

17 The Monastery Library, sign. A IV. Z. a. 8; for more information, see DOKOUPIL, Vladislav. Soupis rukopisů knihovny augustiniánů na Starém Brně. Praha 1957, p. 16, sign. A 7.

18 DOKOUPIL, Vladislav. Dějiny moravských kläšternich knihoven, op. cit., p. 100.

19 Not yet discovered. 
Another fateful episode in the history of the monastery library was in the year 1950 when all monasteries still active in what was then Czechoslovakia were abolished, and the entire contents of the library and other archival materials had to be transferred and rearranged in the shortest time possible. Fortunately in the case of southern Moravia, this process was conducted through the University library in Brno, and thanks to this oversight, losses seem to be quite insignificant in comparison to other regions of the former Czechoslovakia. The monastery library at Staré Brno was newly revised and partially divided. Vladislav Dokoupil and his colleagues worked sometime after 1950 with local lists made by Pazderka. Dokoupil states that these lists enabled the entire revision to proceed smoothly. ${ }^{20}$ After returning the library in 1997 from the former Brno University Library (now the Moravian Library) back to the monastery of the Augustinians, most of the books were placed in their original locations according to Pazderka's revision lists. Only a portion of the newer Augustinian literature and the entire collection of manuscripts remain presently deposited in the Brno University Library. ${ }^{21}$

Only prints are kept today in the monastery library, deployed without any logic. A printed catalogue of the music prints and literature, published in 1957 by Vladislav Dokoupil and Vladimír Telec, enabled the present search for these prints. ${ }^{22}$ About two dozen musical prints from the Augustinian monastery library were selected from this list. These could theoretically have belonged to the original music department labeled Q. Fortunately, Dokoupil's catalogue also contains information about the original signatures and locations in the library according to Pazderka's ordering system. Pazderka had created four-digit shelfmarks consisting of a Roman number indicating the room ( $\mathrm{I}-\mathrm{V}$, whereby the main hall is marked $\mathrm{V}$, the first room behind the main hall is marked IV, etc.), shelf markings (alphabetical letters A-Z), designated shelves (starting from the lowermost shelf with the designation a-l) and a number indicating the order of the bundle in the shelf. Today, this signature is preceded by the letter A, so as to designate the Augustinian monastery library. The signature thus looks like this: A I. A. a. $1 .^{23}$

From this selection of music prints, four prints with the standard Q ST label were found in the monastery library. The oldest musical print among them, Novi thesauri musici liber primus edited by Pietro Joannelli, was published in Venice in 1568 by Antonio Gardano. In addition to this first book, the binder's volume includes four other prints titled Novi atque catholici thesauri musici. ${ }^{24}$ All five partbooks (cantus, tenor, altus, bassus,

20 DOKOUPIL, Vladislav. Dějiny moravských klášternich knihoven, op. cit., p. 127.

21 See DOKOUPIL, Vladislav. Soupis rukopisủ knihovny augustiniánů na Starém Brně. Brno 1957.

22 DOKOUPIL, Vladislav - TELEC, Vladimír. Hudebni staré tisky ve fondech Universitni knihovny v Brně. Brno 1957.

23 DOKOUPIL, Vladislav. Dẽjiny moravských klášterních knihoven, op. cit., p. 127.

24 Novi thesauri musici liber primus, quo selectissime planeque novae, nec unquam in lucem editae cantiones sacrae, quas vulgo moteta vocant continentur, octo, septem, sex, quinque ac auatuor vocum, a praestantissimis ac huius aetatis precipuls symphoniacis compositae, quae in sacra Ecclesia catholica summis solemnibusque festivitatibus canuntur, ad omnis generis instrumenta musica accomodatae: Petri Joannelli bergomensis de Gandino, summo studio ac labore collectae elusque expensis impressae. Venezia, Antonio Gardano, 1568; Novi atque catholici thesauri music, liber secundus, quo selectissime [...] Venezia, Antonio Gardano, 1568; Novi atque catholici thesauri musici, liber tertius, quo selectissime [...] Venezia, Antonio Gardano, 1568; Novi atque 
sextus) have been preserved in the library. The binding of each book is stamped with the monogram ACPST, the abbreviation of the name of prior of the monastery at that time (Augustinus Clementinus Praepositus Sanctae Thomae), in contrast to Theodora Straková's claim that the monogram is only on the cantus part book. ${ }^{25}$

Augustin Clement was the prior of the Augustinians in Brno between the years 1573 and 1594. During that time he managed to improve the economic situation of the monastery, which had been in decline. For this reason, liturgical music in the church of St. Thomas needed to be restored, and some contemporary music prints were purchased..$^{26}$ Specifically, the Novus thesaurus musicus was acquired in 1582. In addition to this print, Augustin Clement purchased other volumes until his death in 1594. Palestrina's second book of masses and other prints now deposited in the Department of Music History of the Moravian Museum in Brno most probably belong to this very first collection of music. ${ }^{27}$ Therefore, Vladislav Dokoupil's claim that "Augustin Clement did not particularly enrich the library" 28 appears to be inaccurate.

Two other prints belonging to signature $Q$ still preserved in the monastery library are music-theory treatises: De tutte l'opere by Gioseffo Zarlino and L'arte del contraponto by Giovanni Maria Artusi. The peculiarity of these two prints is based on the fact that they are bound together as a single volume. Zarlino's De tutte l'opere ${ }^{29}$ contains four volumes in the original, but only the first two are found in the Brno exemplar. The first volume is the fourth edition of Zarlino's tract Le Institutioni Harmoniche and the second volume includes the second edition of Le Dimostrationi, both published in 1589 in Venice by Francesco de' Franceschi. These two treatises by Zarlino are followed by two editions of Artusi's L'arte del contraponto, printed in 1586 and 1589 in Venice (G. Vincenzi and R. Amadino). ${ }^{30}$

The last musical print in the Monastery Library once catalogued under shelfmark $Q$ is the printed liturgical book Manuale chorale, which contains hymns, psalms, antiphons

catholici thesauri musici, libert quartus, quo selectissime [...], Venezia, Antonio Gardano, 1568; Liber quintus et ultimus, quo variae, tum sacrae, tum aliis etiam locis honestissimis competentes ac congruis, plane novae, neque unquam antea, a quopiam in lucem editae harmoniae comprehenduntur [...] Venezia, Antonio Gardano, 1568. The Monastery Library, sign. A II. G. b. 11; RISM A/I: 1568 2-6; DOKOUPIL - TELEC, op. cit., p. 29-30, Nr. 111.

25 STRAKOVÁ, Theodora. Vokálně polyfonní skladby, op. cit., p. 154.

26 Cf. EDWARDS, Scott Lee. Repertory Migration in the Czech Crown Lands, 1570-1630. Dissertation. University of California, Berkeley 2012, p. 74, who draws attention to the possible acquisition of prints mentioned by STRAKOVÁ, Theodora. Vokálně polyfonní skladby, op. cit.

27 STRAKOVÁ, Theodora. Vokálně polyfonní skladby, op. cit., p. 154; MAŇAS, Vladimír. Hudebni kultura, op. cit.

28 DOKOUPIL, Vladislav. Dějiny moravských klášterních knihoven, op. cit., p. 86.

29 De tutte l'opere del R. M. Gioseffo Zarlino da Chioggia, Maestro di Cappella della Serenissima Signoria di Venetia. Venetia, Francesco de Franceschi, 1589. The Monastery Library, sign. A I. H. a. 1; DOKOUPIL - TELEC, op. cit., p. 105-106, Nr. 429.

30 L'arte del contraponto ridotta in tavole da Gio: maria Artusi da Bologna. Dove brevemente si contiene i Precetti a quest Arte necessarii. Venetia, Giacomo Vincenzi a Ricciardo Amadino, 1586; Seconda parte dell'arte del contraponto. Nella quale si tratta dell'utile \& uso delle Dissonanze. Divisa in due libri... Nouamente Data in luce. Venetia, Giacomo Vincenti 1589. The Monastery Library, sign. A I. H. a. 1, adl.; DOKOUPIL - TELEC, op. cit., p. 6, Nr. 21. 
and other choral chants. ${ }^{31}$ The print comes from the Venetian workshop of the Giunta family from 1597. The printer's mark (Lucantonia Giunti) is found on the last folio in this book. The print lacks a title page, the first preserved folio being an index of psalms. The label on the back of the book states Manuale chorile (!) seu Antiphonarium: Venetiis, and Dokoupil describes it as "Manuale chorile (!) in quo capitula, orationes, Antiphone, Omnesque Hymni cum suo cantu per totum annum inseruntur." 32 Based on a comparison with the same print from the Spanish National Library in Madrid, ${ }^{33}$ the entire original title of this publication should be Manuale chorale omnibus ecclesiasticis horas diurnas atque nocturnas in choro psallentibus apprime necessarium [...], which contains the Gregorian calendar and several hymns and psalms. This is then followed by the second part of the print, which is called Manuale chorile in quo capitula, orationes, Antiphone, Omnesque Hymni [...]. The word "chorile" is thus misleading and probably occurred as a result of a simple printing error in the second part of the book.

Additional musical prints from the original music collection in the monastery library have yet to be discovered. However, it has to be said that many prints were likely lost over the years. Liturgical books that were regularly used in the liturgy also belonged among the musicalia, such as the Antiphonarium Romanum de tempore printed in 1687 in Venice. ${ }^{34}$ This liturgical book is located today in the main hall of the monastery library and, due to its large format, is placed in the lower cabinet under the bookshelf with the letter M. Surprisingly, this antiphonary does not contain the expected label Q ST. This is likely due to its regular use within the everday liturgy, and therefore this volume was not part of the library in the $18^{\text {th }}$ century. However, this discovery outlines the larger scope of musical practice in the monastery and leads to a better understanding of the original content and the division of the monastery library. ${ }^{35}$

The monastery library is not the only institution in which the musicalia of Augustinians have survived. The collection of manuscripts from the monastery library has been deposited in the Moravian Library since 1951 (hereinafter ML). Vladislav Dokoupil published a catalogue of this collection in 1957 under the title Soupis rukopisu knihovny augustiniánů na Starém Brně. ${ }^{36}$ The collection of manuscripts consists in total of 134 volumes, mostly liturgical books from the medieval phase of the convent, namely missals, graduals, antiphonaries or books about St. Augustine; also preserved among them are the two later catalogues of the library from the $18^{\text {th }}$ century with the signatures A 3 and

31 Manuale chorile in quo capitula, orationes, Antiphone, Omnesque Hymni cum suo cantu per totum annum inseruntur. Venetiis, ap. Iuntas, 1597. The Monastery Library, sign. A I. I. b. 11; DOKOUPIL - TELEC, op. cit., p. 41, Nr. 149.

32 DOKOUPIL - TELEC, op. cit., p. 41, Nr. 149.

33 Biblioteca Nacional de España, sig. R/ 9256; available online from: <http://bdhrd.bne.es/viewer. vm?id=0000160021\&page $=1>$

34 Antiphonarium Romanum de tempore, et Sanctis Ad Ritum Breviarii [...] Venetiis, apud Cieras 1687. The Monastery Library, sign. A V. M. aa. 2; DOKOUPIL - TELEC, op. cit., p. 4, Nr. 14.

35 The antiphonary is significant proof of the musical practice of St. Tomas thanks to a number of handwritten notes. On the back side are signatures of three young musicians, members of the monastery foundation, from 1755, who added some new chants intended specifically for the needs of the monastery.

36 DOKOUPIL, Vladislav. Soupis rukopisů knihovny augustiniánů na Starém Brně. Praha 1957. 
A 7. Of the total of 134 manuscripts, eleven of them includes notations, but only one of them bears the label Q ST. This is a medieval antiphonary bearing the shelfmark A 57, ${ }^{37}$ which dates back to the mid- $14^{\text {th }}$ century and features quadratic choral notation, typical for this period. Because of its date and content, it is likely that this manuscript formed the oldest part of the Augustinian monastery library, which served the Order for liturgical purposes. Other manuscripts from this collection do not bear the $Q$ shelfmark, most probably for the same reason that applies to the printed antiphonary from the $17^{\text {th }}$ century: codices were located directly in the church for regular use in the liturgy.

At a certain point, most probably after the reorganization of the library by Pazderka, some of the musicalia were transferred from the monastery library to the choir loft and added to the music collection. Vladislav Dokoupil thus was unaware of these prints and manuscripts, but a description can be found in an article about the Augustinian music collection in Staré Brno published by Bohumír Štědroň in 1943. ${ }^{38}$ At the beginning of his article, Štědroň describes the musicalia from the $16^{\text {th }}$ and $17^{\text {th }}$ centuries kept in the choir loft of the Church of the Assumption of the Virgin Mary at the Augustinian monastery in Staré Brno on one of the seven high shelves. The oldest layer of the music codices had been located in the department marked letter A. ${ }^{39}$ Štědroň's description was the very first attempt to evaluate the oldest musical materials and to find more information about them. Thanks to the author's work, it is now possible to compare the musicalia physically preserved in the Department of the History of Music of the Moravian Museum in Brno (DHM MM), where they were deposited in 1951, with the constitution of the music collection that had been deposited directly in the choir loft at Staré Brno before 1943. However, the primary question remains still unsolved: when had the musicalia been split from the original department labeled $\mathrm{Q}$ ? This must have happened at the beginning of the 20th century when the new catalogue of the library was prepared. Pazderka destroyed the original thematic structure of the library, and the musicalia from the library were transferred to a later collection of music sheets used in the contemporary performance of liturgical music.

Basic information about the overall music collection deposited in the DHM MM can be found in the guide to the archival collections of the music department of the Moravian Museum from $1971 .^{40}$ Unfortunately, this list does not include all titles nor their original signatures. A later guide (2007) captures new acquisitions and includes more detailed information about early music prints and manuscripts. ${ }^{41}$ Usually, information from both guides matches, but it is also occasionally evident that the later guide does

37 Moravian Library, Fond of Manuscripts, Ms. A 57: Antiphonarium.

38 ŠTĚDROŇ, Bohumír. Hudební sbírka Augustiniánů na Starém Brně. Věstnik České akademie věd a umění, 1943, Nr. 52, p. 1-29. For more information on the music collection, see SEHNAL, Jiří. Hudba u brněnských augustiniánů v 18. století. Hudebni věda, 1983, 20, Nr. 3, p. 231-241.

39 ŠTĚDROŇ, Bohumír. Hudební sbírka Augustiniánů na Starém Brně, op. cit., p. 1.

40 STRAKOVÁ, Theodora - SEHNAL, Jiří - P̌̌IBÁŇOVÁ, Svatava. Prưvodce po archivnich fondech Ústavu dějin hudby Moravského musea v Brně. Brno, 1971.

41 KYAS, Vojtěch. Prưvodce po archivnich fondech II Odděleni dějin hudby Moravského zemského muzea. Brno, 2007. 
not contain all the items quoted in the first guide and vice versa. The enclosed table of musicalia provides evidence for these differences related to each title. Straková also mentions Renaissance music prints from the Augustinian monastery in the last part of her thorough study of renaissance repertoires in Moravia. She also provides a detailed list of all music prints then known to have been preserved in various Moravian museums, archives and libraries. ${ }^{42}$

In total, there are fifteen prints and two manuscripts from the $16^{\text {th }}$ and $17^{\text {th }}$ centuries in the DHM MM which can be identified as having been part of the original music library of the Augustinian monastery library, based on similar bindings and the original label Q ST. The oldest print, which has been described by Bohumír Štědroň and Theodora Straková $^{43}$ and is preserved in the DHM MM, is the famous and widespread edition of the Novum et insigne opus musicum from 1558 with two later editions, Secunda pars magni opera music and Tertia pars magni operis musici, both published in Nuremberg in $1559 .{ }^{44}$ All three prints include motets of well- and lesser-known composers of Franco-Flemish Renaissance polyphony represented primarily by Josquin Desprez and Jacobus Clemens non Papa. Only two part books (tenor and vagans) survive in Brno.

Ordered chronologically, the Thesaurus musicus, printed by Montanus and Neuber in Nürnberg in 1564, ${ }^{45}$ is the second oldest print. Seven partbooks are preserved from the Augustinian library in Brno, with two partbooks serving potentially as duplicates. Hence, this collection could have been acquired as multiple sets of partbooks. Neither Štědroň nor Straková's guide from 1971 mentions this edition. A description of these partbooks did not appear until 1983 in the aforementioned paper by Theodora Straková and again in the later guide from $2007 .{ }^{46}$

42 STRAKOVÁ, Theodora. Vokálně polyfonní skladby, op. cit., p. 149-180.

43 ŠTĚDROŇ, Bohumír. Hudební sbírka, op. cit., p. 1; STRAKOVÁ, Theodora. Vokálně polyfonní skladby, op. cit., p. 168, Nr. 93, 94, 95.

44 Novum et insigne opus musicum, sex, quinque et quatuor vocum, cujus in Germania hactenus nihil simile, usquam est editum. Nunc qudem Iocupletatum plus cenum non minus elegantibus carminigus, tum Iosquini, tum aliorum clarissimorum symphonistarum tam veterum quam recentiorum, quorum quaedam antehac sunt edita, multa nunc primum in lucem exeunt [...] Cantionum sex vocum. Nürnberg, J. Montanus et U. Neuber, 1558; Secunda pars magni operis musici [...] Quinque vocum. Nürnberg, J. Montanus et U. Neuber, 1559; Tertia pars magni operis musici [...] Quatuor vocum. Nürnberg, J. Montanus et U. Neuber, 1559. The Department of the History of Music in Moravian Museum (hereinafter DHM MM), A 20529 a-b (tied as a whole); RISM A/I: $1558^{4}$, RISM A/I: $1559^{1-2}$.

45 Thesaurus musicus continens selectissimas octo, septem, sex, quinque et quatuor vocum harmonias, tam a veteribus quam recentioribus symphonistis compositas et ad omnis generis instrumenta musica accomodatas [...] Tomi primi continentis cantiones octo vocum [...] Nürnberg, J. Montanus et U. Neuber, 1564; Thesauri musici tomus secundus continens optimas septem vocum cantiones ex variis autoribus collectas [...] Nürnberg, J. Montanus et U. Neuber, 1564; Thesauri musici tomus tertius continens cantiones sacras, quas vulgo motetas vocant, ex optimis musicis selectas, Sex vocum [...] Nürnberg, J. Montanus et U. Neuber, 1564; Thesauri musici tomus quartus continens selectissimas, quinque vocum harmonias, quas vulgo Motetas vocant [...] Nürnberg, J. Montanus et U. Neuber, 1564; Thesauri musici tomus quintus et ultimus, continens sacras harmonias quatuor vocibus compositas [...] Nürnberg, J. Montanus et U. Neuber, 1564. DHM MM; A 20535 a-e; RISM A/I: 1564 $4^{1-5}$. 46 STRAKOVÁ, Theodora. Vokálně polyfonní skladby, op. cit., p. 168-169, Nr. 97-101; KYAS, op. cit., p. 77. 
The edition of Palestrina's Missarum liber secundus (Rome 1567) (77 $^{4}$ includes four mass settings for four voices (Missa De Beata Virgine, Missa inviolata, Missa sine nomine a Missa ad fugam), two for five (Missa Aspice domine, Missa salvum me fac) and finally the famous Missa Papae Marcelli for six voices. The Brno exemplar lacks the title page as well as the first folio containing the index, and hence begins immediately with the Missa de Beata Virgine. ${ }^{48}$ According to RISM, this print is preserved in 25 exemplars, but within the Czech Republic, this choirbook from Brno seems to be unique.

The Quartus tomus Musici Operis by Jacobus Handl Gallus, printed in Georg Nigrin's office in Prague in 1590, is preserved in four part books. ${ }^{49}$ These four editions mentioned thus far together with Joanelli's print Novi thesauri musici were most likely acquired for the convent in the time when Augustinus Clementinus (1574-1594) held the office of prior.

Only the cantus partbook is preserved in the case of the Sacrae symphoniae, published in Nuremberg in 1598 by Paul Kaufmann..$^{50}$ This collection, edited by the Nuremberg organist Caspar Hassler, contains motets for four to sixteen voices. Unfortunately, this partbook has been severely damaged. Its binding has disintegrated (although the label with the signature Q ST has been preserved in a diminished state), and the title page, dedication by the editor, index and some of the first compositions are missing. This exemplar is also bound with Sacrarum Symphoniarum continuatio (Nuremberg 1600), transmitting works by 35 composers. ${ }^{51}$

A binder's volume of four prints (masses by Jacob Regnart and Narcissus Zängel, motets by Andrea Pevernage and a collection of Bicinia) appears without the important Q ST label due to its highly damaged binding. Thanks to some remains from the blackbrown paper of the binding, this binder's volume can be identified as a former part of the Augustinian musicalia collection. Five partbooks from a complete set of six are preserved, including Cantus, Altus, Tenor, Quinta and Sexta vox; only the bassus partbook

47 Joannis Aloysii Prenestini Basilica S. Petri de urbe capellae magistro Missarum liber secundus.Romae apud. heared. Valerii et Aloysii Doricorum fratrum Brixiensium, 1567. DHM MM; A 20532 (here under the title Missa de Beata Virgine); RISM A/I: P 660; PP 660.

48 KYAS, op. cit., quotes this print only as "Missa de Beata Virgine“" p. 77, although already Bohumír Štědroň identified this print correctly in 1943 and under its proper title it quotes also Theodora Straková, who did not recognise its choir book form; see ŠTĚDROŇ, Bohumír. Hudební sbírka, op. cit., p. 1.; STRAKOVÁ, Theodora. Vokálně polyfonní skladby, op. cit., p. 161, Nr. 43.

49 Quartus tomus Musici Operis harmoniarum quatuor, quinque, sex, octo et plurium vocum, quae ex sancto catholicae Ecclesiae usu ita sunt dispositae, ut omni tempore inservire queant [...] Authore Jacobo Handl. Pragae, typis Georgii Nigrini. Anno MDXC (1590). DHM MM 20530 a-d; RISM A/I: H 1985; HH 1985. For the Brno exemplar see ŠTĚDROŇ, Bohumír. Hudební sbírka, op. cit., p. 1.; STRAKOVÁ, Theodora. Vokálně polyfonní skladby, op. cit., p. 158, Nr. 15; KYAS, op. cit., p. 77.

50 Sacrae symphoniae, diversorum excellentissimorum authorum. Quaternis, 5. 6. 7. 8. 10. 12. et 16. vocibus, tam vivis, quam instrumentalibus accomodatae. Editae studio et opera Casparis Hasleri, S. P. Q. norimberg. organista. Nürnberg, P. Kaufmann, 1598. DHM MM A 20528 (only the cantus partbook is preserved); RISM A/I: $1598^{2}$.

51 Sacrarum Symphoniarum continuatio. Diversorum excelentissimorum authorum. Quaternis, V. VI. VII. VIII. X. et XII. vocibus tam vivis, quam instrumentalibus accomodata. Nürnberg, P. Kaufmann, 1600. DHM MM A 20 528; RISM A/I: 1600². See also ŠTĚDROŇ, Bohumír. Hudební sbírka, op. cit., p. 1; STRAKOVÁ, Theodora. Vokálně polyfonní skladby, op. cit., p. 171, Nr. 115 and 118; KYAS, op. cit., p. 77. 
is missing. ${ }^{52}$ Only a small portion of the title page of Regnart's collection Missae sacrae, printed in 1602 in Frankfurt a. M., has been preserved. ${ }^{53}$ Within the Czech Republic, there is only one another exemplar preserved in the Strahov library in Prague (a sextus partbook). RISM gives false information that the Brno exemplar includes the bassus partbook as well. The lesser-known German composer Narcissus Zängel (also Zangell, Zengell, Zänckhl, Zängli) was born in Augsburg, served as a Sängerknabe in the ducal chapel in Munich under the direction of Orlando di Lasso, and later served as leader of an aristocratic music ensemble in Hechingen. ${ }^{54}$ This collection of six masses titled simply Cantiones sacrae is the only known print by Zängel, published in 1602 by Leonard Formica in Vienna and dedicated to the abbot of the Cistercian abbey in Heiligenkreuz, Paul Schönebner. ${ }^{55}$ Surprisingly enough, two other prints from this binder's volume are not included in RISM. In the case of Pevernage's Cantiones sacrae (Frankfurt 1602), RISM omits the Brno print, but the collection Bicinia, sive cantiones suavissimae duarum vocum (Antwerp 1601) represents an almost unknown and possibly uniquely preserved second (?) edition of this title, first printed by Pierre Phalèse in $1590 .{ }^{56}$ These prints were most probably acquired under the prior Basilius a Carpinetto (1594-1608), although we lack any direct proof. ${ }^{57}$ This could also be the case for the famous Magnum opus musicum by Orlando di Lasso, preserved in Brno in five partbooks with only the cantus missing. ${ }^{58}$

Bohumír Štědroň, who explored the Augustinian music collection before 1943 when it was stored in the choir loft, also mentions a rare print by Johannes Stadlmayr (c.15751648), the Musicae super cantum gregorianum (Ravensburg 1626). ${ }^{59}$ This collection had

52 ŠTĚDROŇ, Bohumír. Hudební sbírka, op. cit., p. 1-2.; STRAKOVÁ, Theodora. Vokálně polyfonní skladby, op. cit., p. 161-172, Nr. 42, 45, 67, 119; KYAS, op. cit., p. 77.

53 Missae sacrae ad imitationem selectissimarum cantionum suavissima harmonia a quinque, sex et octo vocibus iam recens elaboratae: antehac nunquam, nunc autem in Dei laudem et Ecclesiae catholicae usum in lucem edtae: authore [...] Fracofurti, apud W. Richterum, impensis N. Steinii, 1602. DHM MM A 20531 a-e; RISM A/I: R 734.

54 About Zängel see SCHMID, Ernst Fritz. Musik an den schwäbischen Zollernhöfen der Renaissance. Beiträge zur Kulturgeschichte des deutschen Südwestens. Kassel 1962. About the Vienna print see MOTNIK, Marko. Excudebat Leonhardus Formica: Leonhard Formica und seine Musikdrucke. In Musicological Annual, Ljubljana, 2015, vol. 51, Nr. 2, p. 27-40.

55 Cantiones sacrae, quas vulgo missae apellant, sex, octo vocibus in usu ecclesiarum recens editae. Authore Narcisso Zanggel Augustano [...] Viennae Austriae, excudebat Leonh. Formica, 1602. DHM MM sign. A 20531 a-e; RISM A/I: Z 30.

56 The edition of 1601 is mentioned in the inventory of Schlobitten castle. See MÜLLER-BLATTAU, Joseph Maria. Die Erforschung der Musikgeschichte Ostpreßens. In Altpreussische Forschungen, 1926, vol. 3, p. 106 (attachement). For an online edition of the motet Per illud ave prolatum and some notes about the print Bicinia 1601. see TEULING, Arnold den. 27 Duos by Josquin Desprez or not. Assen, 2014. [online 2018-06-04]. Available from <http://home.planet.nl/ teuli049/JosqDuo0Collectie.pdf>

57 STRAKOVÁ, Theodora. Vokálně polyfonní skladby, op. cit., p. 154.

58 Magnum opus musicum Orlandi de Lasso Capellae Bavaricae quondam magistri, complectens omnes cantiones quas motetas vulgo vocant, tam antea editas quam hactenus nondum publicatas II. III. IV. V. VI. VII. VIII. IX. X. XII. vocum [...] Monachii, ex typographia Nicolai Henrici. MDCIV (1604). DHM MM sign. A 20527 a-e. RISM A/I: L 1019; LL 1019. ŠTĚDRON̆, B. Hudební sbírka, op. cit., p. 1-2.; STRAKOVÁ, Theodora. Vokálně polyfonní skladby, op. cit., p. 159, č. 26; KYAS, op. cit., p. 76.

59 RISM A/I: S 4290. 
not been transferred together with other prints to the DHM MM in 1951, so it is most probably lost. Although Štědroň did not make any reference to the binding, Stadlmayr's collection of introits for five voices could originally have also belonged to signature $Q$.

The fifth edition of the Toccate d'intavolatura di cimbalo et organo by Girolamo Frescobaldi (Rome 1637) ${ }^{60}$ once belonged to the composer and trumpeter Pavel Vejvanovský (d. 1693 in Kroměříž). The first book of this collection does not include an inscription from its owner, which was probably simply cut off, whereas the second book features Vejvanovskýs name together with his usual designation as "tubicen campestris" ${ }^{61}$

Vejvanovský donated this print in 1686 to Hieronymus Riemer, member of the convent in Brno and later prior in Jevíčko. Riemer acquired around 130 books, but there is no information about his musical interests. Vejvanovskýs employer, Karl von Lichtenstein-Castelcorno, bishop of Olomouc, travelled to Brno quite often, probably with his music ensemble as well. ${ }^{62}$ Other prints and manuscripts from the Augustinian library, described below, could also have originally belonged to Pavel Vejvanovský, but without direct proof, his ownership remains purely hypothetical.

Two manuscripts with the label Q ST now kept in the DHM MM (D 187, 188) belong to the type of textbooks that were perhaps intended for use in the convent's music foundations. An undated treatise with the title Directorium und Manier written by Alessandro Poglietti $^{63}$ is partially identical with another one of Poglietti's handwritten works, the Compendium: oder kurzer Begriff und Einführung zur Musica, sonderlich einem Organisten dienlich from 1676, which has been preserved in Kremsmünster. ${ }^{64}$ Jiř́i Sehnal has wondered about the absence of such an important treatise by Poglietti in the inventory of the Church of St. Maurice in Kroměřizz from 1695. ${ }^{65}$ According to Christoph Prendl, this manuscript originated around $1678,{ }^{66}$ so it could possibly have belonged to the library of Pavel Vejvanovský before being transferred later to the Augustinian library at Staré Brno, as has proven to be the case of Frescobaldi's collection. Although the binding of this treatise features typical brown-black paper and a label with the signature Q ST, the label gives the title Instructio Organistae M:S: (M:S: as an abbreviation for manuscript),

60 Toccate d'intavolatura di cimbalo et organo, partite di diverse arie e corrente, balletti, ciaccone, passachagli [...] libro primo di Girolamo Frescobaldi. Roma: N. Borbone, 1637; Il secondo libro di toccate, canzone versi d'hinni magnificat gagliarde correnti et altre partite d'intavolatura di cimbalo et organo di girolamo frescobaldi organista in S. Pietro di Roma. In Roma con licenza de superiori 1637 Da Nicolò Borbone. DHM MM sign. A 20547 a-b; RISM A/I: F 1859; FF 1859.

61 Cf. SEHNAL, Jiří. Pavel Vejvanovský and the Kroměřrž music collection: perspectives on sevententh-century music in Moravia. Olomouc, 2008.

62 Cf. STRAKOVÁ, Theodora. Die bischöfliche Musikkapelle in Kremsier und ihre Kontakte zu Brünn. In SEHNAL, Jiří. Musik des 17. Jahrhunderts und Pavel Vejvanovský: Referate von dem gleichnamigen internationalen Symposium in Kroměřž, 6-9. September 1993. Brno, 1994, p. 17-22.

63 Directorium und Manier. DHM MM sign. D 187.

64 A-KE, L 146; Recently see PRENDL, Christoph. Die Musiklehre von Alessandro Poglietti. Teil 1: Kommentar, Teil 2: Kritische Edition. Wilhelmshaven, 2017, see also SEHNAL, Jiří. Varhaníci a varhanní hra na Moravě v 17. a 18. století. Hudebni věda, 1982/19, p. 29-31; SLIMÁČKOVÁ, Jana. Alessandro Poglietti, pohled do života a díla. Diploma thesis, Department of Musicology, Faculty of Arts, Masaryk University, Brno 1996.

65 SEHNAL, Jiří. Pavel Vejvanovský and the Kroměřž music collection, op. cit., p. 175.

66 PRENDL, Teil 1, op. cit., p. 31-33. 
which is in fact the title of the second manuscript from the collection (D 188). This manuscript contains theoretical instructions and compositions in Italian lute tablature notation. ${ }^{67}$ Vice versa, this second and more heterogeneous manuscript bears on its label the title "Modus componendi Musicalia M:S:", which further contributes to the confusion. ${ }^{68}$

Two organ tablatures belong to the collection of the Augustinian library. The older manuscript was described for the first time by the composer Leoš Janáček, who served as a boy in the Augustinian music foundation and was also the last owner of the tablature before it became a part of the DHM MM (A 8 762). ${ }^{69}$ Unfortunately, the binding had largely been damaged already when Leoš Janáček studied it, and during a later renovation of the binding, no records were made about its earlier state. Therefore we can only assume that this manuscript might also belong to signature $Q$. The same situation also applied to tablature D 189.

After the abolition of the monastery in 1950, rich archival materials were deposited in the Moravian provincial archive within the very large collection E 4 (Augustinians of Brno). Surprisingly, this collection of around eleven hundred boxes includes two boxes of musical material mostly from the end of the $18^{\text {th }}$ and the beginning of the $19^{\text {th }}$ centuries (boxes nos. 1040 and 1092). In box no. 1040 there are two manuscripts covered with the brown-black paper and with the label Q ST, therefore originally belonging to the convent library (in contrary to other materials). ${ }^{70}$ The lute tablature titled Variae Ariae et Parthiae does not contain any further information about its provenance, but the existence of two important tablatures of this nature from the monastery, now kept in the DHM MM and Moravian Library, has already attracted attention. ${ }^{71}$ Box no. 1040 also contains a manuscript with French arias titled "Aria et cantus Gallici, Q ST", and according to its title page, Airs De Mons. de mollier, officier dans la musique de la chambre du Roy. ${ }^{72}$ Louis de Mollier (1615-1688) was a French dancer, composer and lute player at the court of Louis the XIV. ${ }^{73}$ Some of his compositions are preserved, but the Brno manuscript seems to be unique in its contents, forty-seven pieces for voice with lute accompaniment

\section{Instructio Organistae. DHM MM sign. D 188.}

68 ŠTĚDROŇ, Bohumír. Hudební sbírka, op. cit., p. 2. See also STRAKOVÁ - SEHNAL - PŘIBÁŇOVÁ. Pri̊vodce po archivnich fondech Ústavu dějin hudby Moravského musea v Brně, op. cit., p. 20.

69 JANÁČEK, Leoš. Starý rukopis notový z archívu Králové kláštera na Starém Brně. Hudebni listy, 1887/1888, č. 4, p. 1-6. STRAKOVÁ, Theodora. Anonymní varhanní tabulatura moravského původu. Časopis Moravského musea, 1950/35, p. 439-455; STRAKOVÁ, Theodora. Starobrněnská varhanní tabulatura. Musikologie, 1958/5, p. 8-48.

70 Moravian provincial archive Brno (MZA); Fond E 4, box Nr. 1092; on these music sheets, see VESELÁ, Irena. Pavel Josef Marek (1748-1806): brněnský augustinián, regenschori a skladatel (paper in print).

71 ŠTudENT, Miloslav. Tajemství falešné identity. Hudebni rozhledy, 2014, Nr. 12, p. 58-59. TREDER, Michael. Augustinian Lute Book. Lute Book Brno, CZ-Bsa E4 1040. 3 volumes. Lübeck: Tree Edition, 2013; Schlegel, Andreas. Die Theorbenzister [online], Accords nouveaux, 2016. [online 2018-05-29]. Available from: 〈http:// www.accordsnouveaux.ch/de/Instrumente/Theorbenzister/Theorbenzister.html>

72 MZA; Fond E 4, box Nr. 1040.

73 BARON, John H. / DUROSOIR, Georgie. Mollier, Louis de. In SADIE, Stanley - TYRREL, John: The New Grove Dictionary of Music and Musicians. 2nd ed. New York: Grove, 2001, p. 906. 
(three of them titled as chansons a boire), which is not concordant with any of his known music. ${ }^{74}$ Among.

Thanks to this research, five manuscripts and eighteen prints that belonged to signature $\mathrm{Q}$ (musicalia) in the Baroque library of the Augustinian convent in Brno have been brought to light. Two additional manuscripts may belong to this collection as well but cannot be verified due to their completely restored binding. At least one print (Stadlmayr's Musicae...) is lost. Regarding the division of these volumes among three to four different places after 1950, this collection has not yet been studied in its original entirety. New findings also contribute to a deeper understanding of the history of music in Brno, since this collection provides valuable data on liturgical music in the monastery of St. Thomas already at the end of the $16^{\text {th }}$ and the whole of the $17^{\text {th }}$ centuries. Moreover, tablatures and other manuscripts that have been preserved support evidence for the performance of secular music in the monastery. The unique character of these manuscripts outlines their European significance.

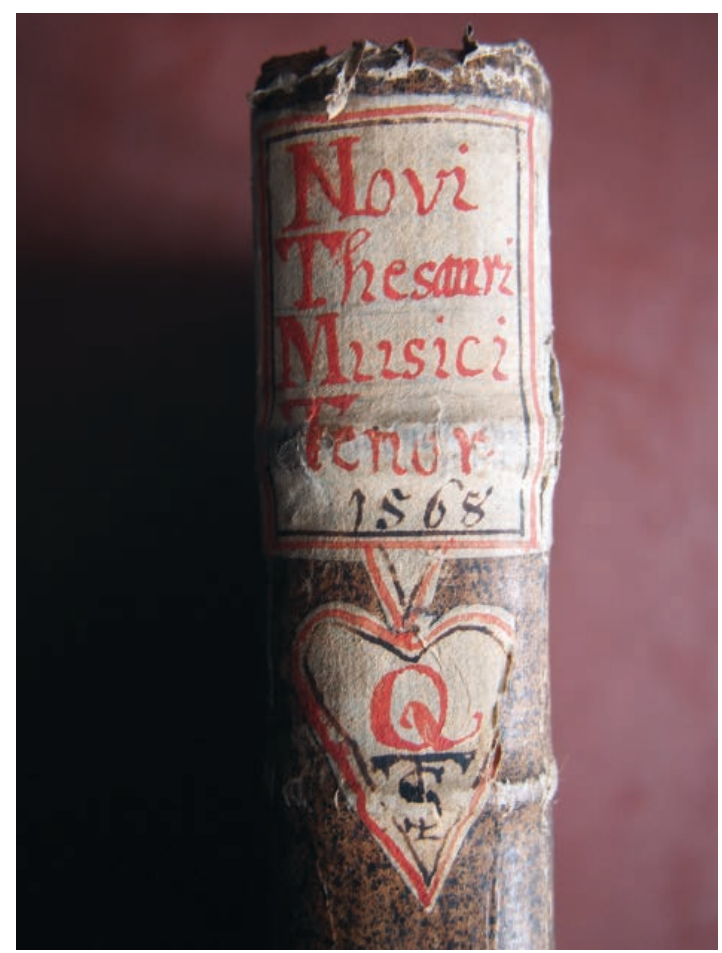

Fig. 1 The paper label with a title and the characteristic mark Q ST. Novi thesauri musici, Pietro Joannelli, 1568, Venezia. Source: The Monastery Library, Staré Brno, sign. A ll. G. b. 11. 


\begin{tabular}{|l|l|l|l|l|}
\hline \multicolumn{5}{|c|}{ THE MONASTERY LIBRARY } \\
\hline Titel: & Author: & Other: & Date: & Sign.: \\
\hline $\begin{array}{l}\text { Novus thesaurus musicus Liber primus } \\
\text { Novi atque catolici thesauri musici Liber se- } \\
\text { cundus, Liber tertius, Libert quartus, Liber } \\
\text { quintus et ultimus }\end{array}$ & $\begin{array}{l}\text { Pietro Joannelli } \\
\text { (ed.) }\end{array}$ & $\begin{array}{l}\text { Print } \\
\text { A. Gardano } \\
\text { Venezia }\end{array}$ & 1568 & A II. G. b. 11 \\
\hline $\begin{array}{l}\text { L'arte del contraponto } \\
\text { Seconda pare dell'arte del contraponto }\end{array}$ & $\begin{array}{l}\text { Giovanni Maria } \\
\text { Artusi }\end{array}$ & $\begin{array}{l}\text { Print } \\
\text { G. Vincenzi, } \\
\text { R. Amadino } \\
\text { Venezia }\end{array}$ & $\begin{array}{l}1586, \\
1589\end{array}$ & $\begin{array}{l}\text { A I. H. a. 1, 1, } \\
\text { priv. }\end{array}$ \\
\hline $\begin{array}{l}\text { De tutte l'opere } \\
\text { sv. 1 - Le Institutioni harmoniche, } \\
\text { sv. 2- Le Dimostrationi }\end{array}$ & Gioseffo Zarlino & $\begin{array}{l}\text { Print } \\
\text { F. Francesci } \\
\text { Venezia }\end{array}$ & 1589 & A I. H. a. 1 \\
\hline $\begin{array}{l}\text { Manuale chorile (chorale) in quo capitula, } \\
\text { orationes, Antiphone, Omnesque Hymni } \\
\text { cum suo cantu per totum annum inseruntur }\end{array}$ & x & $\begin{array}{l}\text { Print } \\
\text { L. Giunti } \\
\text { Venezia }\end{array}$ & 1597 & A I. I. b. 11 \\
\hline
\end{tabular}

Tab. 1 List of preserved volumes with $Q$ in the Library of the Augustinian Monastery at Staré Brno.

\begin{tabular}{|l|c|l|l|l|}
\hline \multicolumn{7}{|c|}{ MORAVIAN LIBRARY } \\
\hline Titel: & Author: & Other: & Date: & Sign.: \\
\hline Antiphonarium & $\mathrm{x}$ & Manuscript & $\begin{array}{l}\text { 2nd half of the 14th } \\
\text { century }\end{array}$ & A 57 \\
\hline
\end{tabular}

Tab. 2 List of preserved volumes with Q in the Moravian Library in Brno.

\begin{tabular}{|c|c|c|c|c|}
\hline \multicolumn{5}{|c|}{ DEPARTMENT OF THE HISTORY OF MUSIC IN MORAVIAN MUSEUM } \\
\hline Titel: & Author: & Other: & Date: & Sign.: \\
\hline Novum et insigne opus musicum & 26 authors & \multirow{3}{*}{$\begin{array}{l}\text { Print } \\
\text { J. Montanus \& } \\
\text { U. Neuber } \\
\text { Nürnberg }\end{array}$} & 1558 & A $20529 a-b$ \\
\hline Secunda pars magni operis musici & 25 authors & & 1559 & A $20529 a-b$ \\
\hline Tertia pars magni operis musici & 18 authors & & 1559 & A $20529 a-b$ \\
\hline Thesaurus musicus & 70 authors & $\begin{array}{l}\text { Print } \\
\text { J. Montanus \& } \\
\text { U. Neuber } \\
\text { Nürnberg }\end{array}$ & 1564 & A 20535 a-e \\
\hline Missarum liber secundus & $\begin{array}{l}\text { Giovanni Pierluigi } \\
\text { Palestrina }\end{array}$ & $\begin{array}{l}\text { Print } \\
\text { Valerio \& Aloysio } \\
\text { Dorico } \\
\text { Rom }\end{array}$ & 1567 & A 20532 \\
\hline Selectiores quadem missae ${ }^{75}$ & $\begin{array}{l}\text { Jacobus Handl } \\
\text { Gallus }\end{array}$ & \begin{tabular}{|l|} 
Print \\
J. Nigrin \\
Praha
\end{tabular} & 1580 & A 24312 \\
\hline
\end{tabular}

75 Selectiores quaedam missae, pro ecclesia dei non inutiles, nunc primum in lucem datae ac correctae ab authore Jacobo Hándl. Missarum IIII. vocum, liber I.; Missarum V. vocum, liber I.; Missarum VI. vocum, liber I.; Missarum VII. et VIII. vocum, liber I. - Pragae, ex officina Nigriniana, Anno MDLXXX (1580). 1 sv. - Cantus; RISM A/I: H 1976; H 1977; H 1978; H 1979. The information about the Selectiones quadam missae is not included above, because the print was discovered after the submission of the paper. 


\begin{tabular}{|c|c|c|c|c|}
\hline \multicolumn{5}{|c|}{ DEPARTMENT OF THE HISTORY OF MUSIC IN MORAVIAN MUSEUM } \\
\hline Titel: & Author: & Other: & Date: & Sign.: \\
\hline Quartus tomus Musici Operis & $\begin{array}{l}\text { Jacobus Handl } \\
\text { Gallus }\end{array}$ & \begin{tabular}{|l} 
Print \\
J. Nigrin \\
Praha
\end{tabular} & 1590 & A 20530 a-d \\
\hline $\begin{array}{l}\text { Sacrae symphoniae diversorum } \\
\text { excellentissimorum authorum }\end{array}$ & 19 authors & \begin{tabular}{|l|} 
Print \\
P. Kaufman \\
Nürnberg
\end{tabular} & 1598 & A 20528 \\
\hline $\begin{array}{l}\text { Sacrarum Symphoniarum } \\
\text { continuatio }\end{array}$ & 35 authors & \begin{tabular}{|l|} 
Print \\
P. Kaufman \\
Nürnberg \\
\end{tabular} & 1600 & A 20528 \\
\hline $\begin{array}{l}\text { Bicinia, sive cantiones } \\
\text { suavissimae duarum vocum }\end{array}$ & Various & \begin{tabular}{|l|} 
Print \\
P. Phalèse \\
Antwerpen
\end{tabular} & 1601 & A 20531 a-e \\
\hline Missae sacrae & Jacob Regnart & \begin{tabular}{|l|} 
Print \\
W. Richter \& N. \\
Steinius \\
Frankfurt \\
\end{tabular} & 1602 & A 20531 a-e \\
\hline Cantiones sacrae & Narciss Zängel & \begin{tabular}{|l|} 
Print \\
L. Formica \\
Wien \\
\end{tabular} & 1602 & A 20531 a-e \\
\hline Cantiones sacrae & Andrea Pevergnage & \begin{tabular}{|l|} 
Print \\
W. Richter \& N. \\
Steinius \\
Frankfurt \\
\end{tabular} & 1602 & A 20531 a-e \\
\hline Magnum opus musicum & Orlando di Lasso & \begin{tabular}{|l|} 
Print \\
N. Henricus \\
München \\
\end{tabular} & 1604 & A 20527 a-e \\
\hline $\begin{array}{l}\text { Toccate d'intavolatura di cimbalo } \\
\text { et organo }\end{array}$ & Girolamo Frescobaldi & \begin{tabular}{|l|} 
Print \\
N. Borbone \\
Rom
\end{tabular} & 1637 & A $20547 a-b$ \\
\hline Directorium und Manier & Alessandro Poglietti & Manuscript & after 1678 & D 187 \\
\hline Instructio Organistae & Anon. & Manuscript & $?$ & D 188 \\
\hline
\end{tabular}

Tab. 3 List of preserved volumes with Q in the Department of the History of Music in Moravian Museum in Brno.

\begin{tabular}{|l|c|l|l|l|}
\hline \multicolumn{5}{|c|}{ MORAVIAN PROVINCIAL ARCHIVE } \\
\hline Titel: & Author: & Other: & Date: & Sign.: \\
\hline Variae Ariae et Parthiae & $\mathrm{x}$ & Manuscript & $?$ & $\begin{array}{l}\text { E 4; karton } \\
\text { ć. 1040 }\end{array}$ \\
\hline Aria et cantus Gallici & Louise de Mollier?76 & Manuscript & $?$ & $\begin{array}{l}\text { E 4; karton } \\
\text { č. 1040 }\end{array}$ \\
\hline
\end{tabular}

Tab. 4 List of preserved volumes with Q in the Moravian Provincial Archive in Brno, fond E 4 Augustiniáni - Staré Brno.

76 The newly discovered manuscript is the subject of current research at the Department of the Musicology, MU Brno. 


\section{Bibliography}

BARON, John H. - DUROSOIR, Georgie. Mollier, Louis de. In SADIE, Stanley - TYRREL, John: The New Grove Dictionary of Music and Musicians. 2nd ed. New York: Grove, 2001, p. 906.

DOKOUPIL, Vladislav. Soupis rukopisů knihovny augustiniánů na Starém Brně. Praha 1957.

DOKOUPIL, Vladislav. Dějiny morauských klášternich knihoven ve správě Universitní knihovny v Brnĕ. Brno, 1972.

DOKOUPIL, Vladislav - TELEC, Vladimír. Hudebni staré tisky ve fondech Universitni knihovny v Brnè. Brno, 1957.

EDWARDS, Scott Lee. Repertory Migration in the Czech Crown Lands, 1570-1630. Dissertation. University of California, Berkeley, 2012.

HORYNA, Martin - MAŇAS, Vladimír. Two Manuscripts of Polyphonic Music in Brno from the Mid-Sixteenth Century. Early Music, 2012, 40, N. 4, p. 553-575.

JANÁČEK, Leoš. Starý rukopis notový z archívu Králové kláštera na Starém Brně. Hudebni listy, $1887 / 1888$, Nr. 4, p. 1-6.

JANETSCHEK, Clemens d'Elpidio. Necrologia Patrum et Fratrum Ord. Erem. calceat. S. Aug. in vicariatu Moraviae ab anno 1363-1888 defunctorum. Brunae, 1894.

JANETSCHEK, Clemens d'Elpidio. Das Augustiner-Eremitenstift S. Thomas in Brünn. Bd. 1, Brünn, 1898.

KYAS, Vojtěch. Prüvodce po archivnich fondech II Odděleni dějin hudby Moravského zemského muzea. Brno, 2007.

MAŇAS, Vladimír. Rukopisy renesanční polyfonie - zapomenutá a přitom cenná součást svatojakubské farní knihovny. In Brno v minulosti a dnes, Archiv města Brna, 2013, vol. 26, p. 39-49.

MAŇAS, Vladimír. Toulky po začátcích hudby v Brně. Brněnská hudebni historie [online] 2013, [cit. 2018-05-28]. Available from: <http://www.mestohudby.cz/publicistika/clanky/toulka-po-zacatcich-hudby-v-brne>.

MAŇAS, Vladimír. Hudba rudolfinské Moravy. In print.

MOTNIK, Marko. Excudebat Leonhardus Formica: Leonhard Formica und seine Musikdrucke. In Musicological Annual, Ljubljana, 2015, vol. 51, Nr. 2, p. 27-40.

PRENDL, Christoph. Die Musiklehre von Alessandro Poglietti. Teil 1: Kommentar, Teil 2: Kritische Edition. Wilhelmshaven, 2017.

SEHNAL, Jiří. Varhaníci a varhanní hra na Moravě v 17. a 18. století. Hudebni věda, 1982, vol. 19, p. 29-31.

SEHNAL, Jiří. Hudba u brněnských augustiniánů v 18. století. Hudebni věda, 1983, vol. 20, Nr. 3, p. 231-241.

SEHNAL, Jiří. Pavel Vejvanovský and the Kroměřżz music collection: perspectives on sevententh-century music in Moravia. Olomouc, 2008.

SCHMID, Ernst Fritz. Musik an den schwäbischen Zollernhöfen der Renaissance. Beiträge zur Kulturgeschichte des deutschen Südwestens. Kassel, 1962.

SLIMÁČKOVÁ, Jana. Alessandro Poglietti, pohled do života a díla. Diplomová práce, Ústav hudební vědy, Filozofická fakulta Masarykovy univerzity, Brno, 1996.

STRAKOVÁ, Theodora. Anonymní varhanní tabulatura moravského původu. Časopis Moravského musea, 1950, vol. 35, p. 439-455.

STRAKOVÁ, Theodora. Starobrněnská varhanní tabulatura. Musikologie, 1958, vol. 5, p. 8-48.

STRAKOVÁ, Theodora - SEHNAL, Jiří - P̌̌IBÁŇOVÁ, Svatava. Prưvodce po archivnich fondech Ústavu dějin hudby Moravského musea v Brně. Brno, 1971. 
STRAKOVÁ, Theodora. Vokálně polyfonní skladby na Moravě v 16. a na počátku 17. století. III. Hudební instituce na Moravě a jejich repertoár. Časopis Moravského muzea, 1983, vol. 68, p. 156-172.

STRAKOVÁ, Theodora. Die bischöfliche Musikkapelle in Kremsier und ihre Kontakte zu Brünn. In SEHNAL, Jiří. Musik des 17. Jahrhunderts und Pavel Vejvanovský: Referate von dem gleichnamigen internationalen Symposium in Kroměrižz, 6.-9. September 1993. Brno, 1994, p. 17-22.

STUDENIČOVÁ, Hana. Kantoři, varhaníci a věžní u sv. Jakuba v Brně v 16. století. In Brno v minulosti a dnes. Archiv města Brna, 2017, vol. 30, p. 127-145.

ŠTĚDROŇ, Bohumír. Hudební sbírka Augustiniánů na Starém Brně. Věstnik České akademie věd a uměni, 1943, vol. 52, p. 1-29.

ŠTĚDROŇ, Bohumír. Základy fundační kapely v Brně před Křížkovským. Slezský sbornik, 1951, vol. 49 , p. $155-183$.

ŠTUDENT, Miloslav. Tajemství falešné identity. Hudebni rozhledy, 2014, Nr. 12, p. 58-59.

TREDER, Michael. Augustinian Lute Book. Lute Book Brno, CZ-Bsa E4 1040. 3 volumes. Lübeck: Tree Edition, 2013; Schlegel, Andreas. Die Theorbenzister [online], Accords nouveaux, 2016. [Cit. dne 2018-05-29]. Available from: 〈http://www.accordsnouveaux.ch/de/Instrumente/ Theorbenzister/Theorbenzister.html>.

TROLDA, Emil. Augustiniáni a hudba. Cyril, 1936, Nr. 1-2, p. 7-10; 1936, Nr. 3-4, p. 29-35.

ZLÁMAL, Bohumil. Komu také děkovati za P. Křížkovského. (Starobrněnský opat Cyril Fr. Napp.) Cyril, 1936, Nr. 3-4, p. 36-38; 1936, Nr. 5-6, p. 60-64, 1936, Nr. 7-8, p. 81-84. 
